Krzysztof Wasilewski

Wojewódzka i Miejska Biblioteka Publiczna

im. Zbigniewa Herberta w Gorzowie Wlkp.

e-mail: k.wasilewski@wimbp.gorzow.pl

\title{
Polonijna prasa wydawana w Stanach Zjednoczonych w latach 1870-1924 w dostępie cyfrowym
}

DOI: http://dx.doi.org/10.12775/TSB.2018.016

STRESZCZENIE: Artykuł przybliża stan liczbowy oraz przedstawia bieżący stan digitalizacji prasy polonijnej, wydawanej w Stanach Zjednoczonych w latach 1870-1924, a więc w okresie największej migracji Polaków. Analizie zostały poddane biblioteki cyfrowe i repozytoria amerykańskie, zarówno niekomercyjne, jak i odpłatne.

SŁowA KLUCzowe: prasa polonijna, imigracja, digitalizacja, biblioteki cyfrowe, USA, Chronicling America.

\section{Wprowadzenie}

elem niniejszego artykułu jest przedstawienie i analiza dotychcza-
sowego stanu digitalizacji prasy polonijnej, wydawanej w Stanach
Zjednoczonych w okresie masowej emigracji polskiej ludności do USA.
Jest to zagadnienie o tyle ważne, iż cyfryzacja zbiorów prasy oraz ich
udostępnienie w internecie może stanowić ważny impuls do badań nad
czasopiśmiennictwem polonijnym w USA. Z jednej bowiem strony digita-
lizacja ułatwia zainteresowanym naukowcom dotarcie do poszczególnych
tytułów, bez ponoszenia wysokich kosztów finansowych i konieczności 
długotrwałych wyjazdów. Z drugiej, oferuje nowe możliwości analityczne, na czele z wykorzystaniem analizy zawartości prowadzonej na dużych zbiorach, których zbadanie - czy to w formie drukowanej, czy w postaci mikrofilmów - przekraczałoby możliwości jednej osoby ${ }^{1}$. Dotychczasowe rezultaty pracy rodzimych i zagranicznych badaczy potwierdzają wysoki potencjał cyfrowych zasobów w różnych dyscyplinach nauki, m.in. historii, politologii czy naukach o mediach ${ }^{2}$. Co więcej, cyfryzacja i powszechny dostęp dają wielu czasopismom „drugie życie”, ocalając je od zapomnienia, nie tylko w profesjonalnych badaniach naukowych, ale także w różnego rodzaju projektach edukacyjnych czy popularyzatorskich ${ }^{3}$. Jednak mnogość i różnorodność cyfrowych bibliotek oraz repozytoriów stawiają przed badaczami konieczność odszukania i wyboru odpowiednich dla ich zainteresowań źródeł i modeli ich udostępniania. Niniejszy artykuł stanowi zatem pewnego rodzaju przewodnik po zasobach zdigitalizowanej prasy polonijnej.

Zgodnie z tytułem artykułu, przyjęte ramy czasowe przypadają na lata 1870-1924. 0 ile data końcowa nie budzi zastrzeżeń, gdyż wiąże się z usankcjonowaniem systemu kwotowego (tzw. Ustawa Johnsona-Reeda), kończącego etap masowej emigracji do USA, o tyle pierwsza data jest umowna. Jak wiadomo, najstarsze polskie osady w USA powstały na długo przed 1870 r. Niemniej, początek faktycznej masowej emigracji

${ }^{1}$ Więcej na ten temat: K. Wasilewski, Co biblioteki cyfrowe mogą zaoferować prasoznawcom?, [w:] Książka, biblioteka, informacja. Między podziałami a wspólnota, t. V, (red.) J. Dzieniakowska, M. Olczak-Kardas, Kielce 2016, s. 649-664.

${ }^{2}$ Por. np. A. Bingham, The Digitization of Newspaper Archives. Opportunities and challenges for historians, "Twentieth Century British History" 2010, vol. 21, s. 225-231; J. Mussel, The Nineteenth-Century Press in the Digital Age, Birmingham 2012; E. Lorang, B.P. Zillig, Electronic text analysis and nineteenth-century newspapers, "Texas Studies in Literature and Language" 2012, vol. 54, s. 303-323. Pośród rodzimych badaczy warto wymienić prace powstałe przy wykorzystaniu cyfrowych zbiorów prasy, m.in. P. Różański, Śmierć Józefa Piłsudskiego i jej percepcja w Stanach Zjednoczonych a zagadnienie żydowskie, „Dzieje Najnowsze” 2008, nr 40, s. 145-157; tenże, ŚmierćJózefa Piłsudskiego w wybranych tytułach prasy amerykańskiej, „Dzieje Najnowsze” 2015, nr 4, s. 41-67; P. Płaneta, Dwie dekady wolności. Obraz Polski na łamach amerykańskich dzienników w latach 1989-2009, „Zeszyty Prasoznawcze” 2011, nr 3-4, s. 100-144; K. Wasilewski, Bezdomnych gromady niemałe... Dyskurs imigracyjny na łamach prasy amerykańskiej (1875-1924), Poznań 2017.

3 Por. H. Wiffjes, Digital Humanities and historical newspaper research [online] [dostęp 3 kwietnia 2016]. Dostępny w World Wide Web: https://www.kb.nl/sites/default/ files/docs/huub-wijfjes-digital-humanities.pdf. 
z ziem polskich do Ameryki Północnej przypada właśnie na lata 70. XIX w., kiedy z zaboru pruskiego przybyło do Stanów Zjednoczonych ok. 150 tys. osób. Zdaniem Andrzeja Paczkowskiego, „nieprzerwana historia prasy polsko-amerykańskiej" rozpoczęła się w 1870 r., wraz z ukazaniem się pierwszego numeru dwutygodnika „Orzeł Polski” ${ }^{4}$. W swojej pracy pt. Polonia amerykańska, Andrzej Brożek przywołuje dane, wedle których stan liczbowy Polonii w USA w 1870 r. wynosił zaledwie 50 tys. osób, lecz już dziesięć lat później wzrósł do 500 tys. W 1910 r. liczbę tę szacowano na trzy miliony 5 . Do 1918 r., a więc do powstania niepodległego państwa polskiego, do USA wyemigrowało kolejne 471 tys. osób. Kolejne lata przyniosły zaostrzenie amerykańskiej polityki imigracyjnej, w związku z czym do 1924 r. do Stanów Zjednoczonych przybyło nie więcej niż sto tysięcy6.

Wyjaśnienia wymaga także termin „prasa polonijna”. Powtarzając za Joanną Raczkowską za taką należy uznać

ogół wydawnictw o charakterze periodycznym, publikowanym poza granicami Polski dla zaspokojenia potrzeb kręgu czytelników polskiego pochodzenia, wydawanych w języku polskim lub obcym, drukowanych lub powielanych innymi metodami ${ }^{7}$.

Inny badacz, Anthony Kuzniewski, dodaje, że wśród głównych celów prasy polonijnej znajdują się

dostarczanie wiadomości o nowym i starym kraju, edukowanie czytelników na temat społeczności etnicznej i warunkach życia w Ameryce oraz spełnianie potrzeb sponsorów - czy to ideowych, czy też towarzyskich lub wynikających z lokalnego konfliktu.

${ }^{4}$ A. Paczkowski, Prasa polonijna w latach 1870-1939. Zarys problematyki, Warszawa 1977, s. 29.

5 A. Brożek, Polonia amerykańska, Warszawa 1977, s. 38.

6 T. Radzik, Polonia amerykańska wobec Polski 1918-1939, Lublin 1990, s. 14.

7 J. Raczkowska, Prasa polonijna w Stanach Zjednoczonych po II wojnie światowej, „Problemy Polonii Zagranicznej” 1975, nr 9.

${ }^{8}$ A.J. Kuzniewski, The Polish-American Press, [w:] The Ethnic Press in the United States. Historical Analysis and Handbook, (red.) S.M. Miller, New York, Westport, London 1987, s. 276. 
Jak widać, prasa polonijna jest pojęciem pojemnym, w związku z czym można do niej zaliczyć różnego rodzaju czasopisma - tak jeśli chodzi o ich wydawców, periodyczność czy zawartość ${ }^{9}$. W związku z tym w niniejszym zestawieniu uwzględnione zostały zarówno dzienniki ogólnoinformacyjne, jak i czasopisma fachowe, związkowe czy religijne. Za główny wyznacznik prasy polonijnej przyjęto docelowego czytelnika danego tytułu.

\section{Polonijna prasa w USA - stan liczbowy}

Określenie stanu liczbowego prasy polonijnej, ukazującej się Stanach Zjednoczonych w latach 1870-1924, jest konieczne do analizy stopnia jej digitalizacji. Za równie ważne należy ponadto uznać określenie zasięgu geograficznego poszczególnych tytułów, aby następnie prawidłowo wyselekcjonować stanowe i lokalne biblioteki cyfrowe. Prasa polonijna w USA była przedmiotem wielu rodzimych i zagranicznych opracowań. Wśród tych pierwszych należy wymienić opracowania Józefa Skrzypka ${ }^{10}$, Romana Nira ${ }^{11}$ czy też Jana Kowalika ${ }^{12}$. Chociaż ta ostatnia praca zawiera przede wszystkim spis tytułów prasowych wydawanych w 1939 r. i później, to część z zamieszczonych w niej czasopism posiada dłuższą historię. Mimo upływu lat, do kanonicznych opracowań nadal zalicza się cytowana już Prasa polonijna w latach 1870-1939 Andrzeja Paczkowskiego, której pierwszy rozdział został poświęcony polonijnemu czasopiśmiennictwu w USA ${ }^{13}$. Z nowszych opracowań warto wymienić artykuł Iwony Leonowicz-Bukały pt. Media polonijne w USA z 2012 r. ${ }^{14}$ Co więcej, niektóre

9 Szeroką definicję prasy polonijnej dostarcza także: J. Lencznarowicz, Prasa i społeczność polska w Australii 1928-1980, Kraków 1994, s. 94.

${ }^{10}$ Np. J. Skrzypek, Początki czasopiśmiennictwa polskiego w Stanach Zjednoczonych $A P$, „Problemy Polonii Zagranicznej” 1960, nr 1, s. 155-186; tenże, Czasopiśmiennictwo polskie w Stanach Zjednoczonych Ameryki Północnej pod koniec XIX wieku (1886-1900), „Rocznik Historii Czasopiśmiennictwa Polskiego” 1963, nr 3, s. 127-169.

11 Np. R. Nir, Prasa polonijna w Ameryce, „Collectanea Theologica” 1982, nr 52, s. 197-206.

12 J. Kowalik, Bibliografia czasopism polskich wydawanych poza granicami Kraju od września 1939 roku, t. 1-4, Lublin 1976.

13 A. Paczkowski, Prasa polonijna...

14 I. Leonowicz-Bukała, Media polonijne w USA, „Komunikacja Społeczna” 2012, nr 4, s. 40-67. 
z tytułów, zwłaszcza te największe, mogące się poszczycić wieloletnią obecnością na rynku, doczekały się swoich monografii ${ }^{15}$.

Z kolei na opracowania amerykańskie dotyczące prasy polonijnej, obok artykułów naukowych, składają się także raporty i analizy tzw. mediów etnicznych, przygotowane przez odpowiednie agencje federalne. Próbę sporządzenia bibliografii ogółu polskiego czasopiśmiennictwa w Stanach Zjednoczonych od początku, tj. od 1842 r. do 1966, podjął m.in. Jan Wępsiec ${ }^{16}$. Ponadto, prasa polonijna jako część prasy etnicznej w USA pojawia się także w encyklopedycznym opracowaniu Lubomyra Wynara ${ }^{17}$ oraz w kolejnych edycjach Ulrich's International Periodicals Directory. Podobny cel przyświecał zestawieniu pt. The Ethnic Press in the United States, wydanemu nakładem American Council for Nationalities Service ${ }^{18}$. Warto także wspomnieć o monumentalnej pracy pod redakcją Dirka Hoerdera pt. The Immigrant Labor Press in North America, 1840s-1970s, której drugi tom został poświęcony czasopiśmiennictwu robotniczemu, wydawanemu przez społeczności imigrantów z Europy Południowej i Wschodniej, w tym Polski ${ }^{19}$. Zdając sobie sprawę, że większość z wymienionych powyżej publikacji powstała w latach 60. i 70. XX w., w związku z czym reprezentują ówczesny stan wiedzy, uzupełniłem je o dane z internetowych katalogów bibliotecznych. Ważnym źródłem była zwłaszcza Biblioteka Kongresu (Library of Congress), tradycyjnie gromadząca ogół wydawnictw, również mniejszości etnicznych.

Pomimo wielości dostępnych źródeł i opracowań, nie sposób ustalić konkretną liczbę polonijnej prasy wydawanej w Stanach Zjednoczonych. Wiele z tytułów zapoczątkowanych w latach 70. XIX w. charakteryzowało się nie tylko efemerycznością i niskim nakładem, lecz także lokalnością, co w konsekwencji utrudniało ich odnotowywanie. Wspomniany już

15 Np. A. D. Jaroszyńska-Kirchman, The Polish Hearst. Ameryka-Echo and the Public Role of the Immigrant Press, Chicago and Springfield 2015; W. Piątkowska-Stepaniak, „Nowy Dziennik” w Nowym Świecie, Opole 2000.

16 J. Wępsiec, Polish American Serial Publications 1842-1966. An Annotated Bibliography, Chicago 1968.

17 L. Wynar, Encyclopedic Directory of Ethnic Newspapers and Periodicals in the United States, Littleton 1972.

18 The Ethnic Press in the United States. Lists of Foreign Language, Nationality and Ethnic Newspapers and Periodicals in the U.S., New York 1974.

19 The Immigrant Labor Press in North America, 1840s-1970s. An Annotated Bibliography, vol. 2, (red.) D. Hoerder, New York-Westport-London 1987. 
„Orzeł Polski”, z którego wydaniem Paczkowski wiąże początek dziejów masowej prasy polonijnej w USA, ukazywał się w miejscowości Washington w stanie Missouri. Wkrótce jednak większość tytułów zaczęła się pojawiać w większych skupiskach polskich imigrantów, zwłaszcza w Chicago. Wśród pierwszych czasopism polonijnych związanych z tym miastem można wymienić „Gazetę Polską Katolicką” (choć początkowo ukazywała się w Detroit), tygodnik „Swobodę”, „Gazetę Polską w Chicago”, ,Przyjaciela Ludu” oraz „Zgodę”, ukazującą się do tej pory ${ }^{20}$. Nieco później, bo na początku lat 80. XIX w., polonijna prasa zaistniała w Nowym Jorku. Były to m.in. takie tytuły jak „Gazeta Nowoyorska”, „Kurier Nowojorski”, „Ogniwo”, „Osa” i „Ziarno”. Jak pisze Nir, do największych ośrodków prasy polonijnej należały wówczas - obok Chicago i Nowego Jorku - Buffalo, Detroit, Milwaukee, Filadelfia, Pittsburgh i Toledo. Podsumowując pierwszy etap rozwoju polonijnych czasopism w Stanach Zjednoczonych, przypadający na lata 1870-1884, Paczkowski określił liczbę ówczesnych tytułów na 17. Większość z nich była związana z Kościołem katolickim lub różnego rodzaju patriotycznymi towarzystwami. Miały one zatem charakter niekomercyjny, a służyły głównie „podniesieniu świadomości religijnej i etnicznej".

W kolejnych latach, zwłaszcza w przedziale czasowym 1885-1892, prasa polonijna zwiększała zarówno swój stan liczbowy, jak i nakład. W samym tylko 1887 r. powstało 15 nowych czasopism, choć część z nich szybko została zamknięta. Dynamiczny rozwój prasy polonijnej wiązał się nie tylko z rosnącym napływem imigrantów, spośród których coraz więcej osób miało już wcześniej kontakt ze słowem pisanym, ale również z okrzepnięciem polonijnych wydawców i dalszą ich profesjonalizacją. Jak wskazuje Paczkowski, w okresie tym istniały co najmniej trzy prężne przedsiębiorstwa wydawnicze należące do osób prywatnych ${ }^{21}$. W 1890 r. powstał „Dziennik Chicagoski”, założony przez zakon Zmartwychwstańców z zadaniem kształtowania postaw czytelników w duchu wiary katolickiej. Warto jednak zauważyć, że ważne tytuły polonijne zaczęły się ukazywać już nie tylko w Chicago i Nowym Jorku, ale także w pozostałych większych skupiskach Polonii. Polonijna prasa pojawiła się m.in. w Minnesocie, Nebrasce i Ohio. W tym ostatnim w 1889 r. zaczął

20 I. Leonowicz-Bukała, Media polonijne...

${ }^{21}$ A. Paczkowski, Prasa polonijna..., s. 34. 
ukazywać się tygodnik „Ameryka w Toledo”, wydawany przez Antoniego Paryskiego, nie bez powodu zwanego później „polskim Hearstem”22. Z kolei rok wcześniej w Wisconsin, dzięki Michałowi Kruszce, zadebiutował pierwszy polonijny dziennik - „Kurier Polski”23. Jak pisze Nir, było to także pierwsze polskie pismo, które zaczęło dołączać dodatek w języku angielskim z przeznaczeniem dla osób nieznających polskiego. 0 powodzeniu „Kuriera Polskiego” świadczy fakt, że w ciągu dwóch lat posiadał on już własną drukarnię i budynek. W latach 1885-1892 powstało nie mniej niż 80 tytułów polonijnych, których łączny jednorazowy nakład wynosił 50 tys. egzemplarzy. Przywołane przez Paczkowskiego dane wskazują ponadto, że o ile w 1887 r. w Chicago ukazywało się 44 proc. wszystkich czasopism polonijnych, o tyle pięć lat później było to już tylko 26 proc. Innymi słowy, prasa polonijna uległa znacznemu rozproszeniu na sześć największych ośrodków w 1892 r. przypadało niespełna 69 proc. wszystkim pism, w porównaniu do 89 proc. w $1887 \mathrm{r}^{24}$

W następnych latach stan liczbowy prasy polonijnej w USA ulegał dalszym przekształceniom, choć - jak zaznacza Paczkowski - od $1892 \mathrm{r}$. liczba tytułów nigdy nie była mniejsza niż $50^{25}$. Na przełomie XIX i XX w. do prasy religijnej i komercyjnej dołączyła także prasa związkowa i radykalna, związana z polskimi gałęziami organizacji socjalistycznych czy komunistycznych. Zdaniem wspomnianego już Hoerdera, polscy imigranci byli jednymi z pierwszych, którzy założyli prasę robotniczą w Stanach Zjednoczonych ${ }^{26}$. Wyprzedzili pod tym względem m.in. Włochów, Finów i Żydów. Tę aktywność niemiecki historyk wiąże z wcześniejszymi doświadczeniami polskich robotników we Francji i Cesarstwie Niemieckim. Trudno określić dokładną liczbę tego rodzaju periodyków, zważywszy na ich często doraźny charakter, niski nakład i efemeryczność. Niemniej, wg obliczeń Hoerdera, polscy, czescy, słowaccy i węgierscy imigranci

${ }^{22}$ Więcej na temat Paryskiego i wydawanej przez niego prasy: A.D. Jaroszyńska-Kirchman, The Polish Hearst...

${ }^{23}$ Na marginesie warto wspomnieć, że wg. R.E. Parkera, pierwszy polonijny dziennik - „Ameryka-Echo” zadebiutował w 1863 r., choć dalsze badania wskazują na błąd amerykańskiego naukowca. Por. R. E. Parker, The Immigrant Press and Its Control, New York and London 1922, s. 252.

24 A. Paczkowski, Prasa polonijna..., s. 37.

25 Tamże, s. 35.

26 The Immigrant Labor Press..., s. 29. 
wydawali na przełomie XIX i XX w. ok. 150 czasopism robotniczych, co stanowiło niemal jedną czwartą ogółu wydawanej przez te społeczności prasy $^{27}$. Łącznie, Polacy dysponowali 47 robotniczymi czasopismami, w tym 11 niezwiązanymi z żadną ideologią, 28 socjalistycznymi, 4 związkowymi i taką samą liczbą komunistycznych ${ }^{28}$. Poszczególne tytuły były wydawane w większych skupiskach robotniczych, co - biorąc pod uwagę strukturę społeczną polskiej imigracji w USA - pod względem geograficznym odpowiadało również tym centrom miejskim, gdzie tradycyjnie osiedlało się najwięcej Polaków.

Polonijne czasopisma przybierały przeważnie postać tygodników, rzadziej dwutygodników i miesięczników. Między innymi z powodów finansowych dzienniki stanowiły rzadkość i do 1892 r. ukazywały się jedynie dwa w języku polskim. Następnie ich liczba zwiększyła się, choć ostatecznie do połowy pierwszej dekady XX w. przetrwało zaledwie sześć. Pośród nich warto wspomnieć o tych związanych z ruchem robotniczym „Robotnik Polski” oraz „Dziennik Ludowy” (następnie „Głos Ludowy”29. Wszystkie dzienniki ukazywały się w największych skupiskach polonijnych, a więc - obok Chicago („Dziennik Chicagoski”, „Dziennik Narodowy”, „Dziennik Polski”) - także w Nowym Jorku („Kurier Nowojorski i Brooklyński”), Detroit („Dziennik Polski”, „Swoboda”), Milwaukee („Dziennik Milwaucki”) i Buffalo („Echo”) ${ }^{30}$. Jedynie niektóre z wymienionych tytułów przetrwały dłużej niż kilka lat, inne - jak „Echo” - z dzienników szybko przeistoczyły się w tygodniki. W pierwszej dekadzie XX w. średnia liczba polonijnych czasopism wahała się między 60 a 70. Większość z nich ukazywała się w nakładzie ok. 2 tys. egzemplarzy, zaś dzienniki rozchodziły się w łącznym nakładzie 60 tys. egzemplarzy. Liczby te różnią się w zależności od źródeł i opracowań, jednak należy zgodzić się z Paczkowskim, gdy szacuje liczbę rozpowszechnianych jednorazowo egzemplarzy prasy polonijnej na początku XX w. na co najmniej 180-200 tys ${ }^{31}$.

Wzrostowi liczby polskich imigrantów w USA towarzyszył wzrost liczby tytułów polonijnych. Szacuje się, że w latach 1905-1919 powstało

\footnotetext{
27 Tamże, s. 29.

28 Tamże, s. 60.

${ }^{29}$ R. Nir, Prasa polonijna w Ameryce..., s. 200.

30 Dane za: W. Kruszka, Historya polska w Ameryce, t. V, Milwaukee 1905.

${ }^{31}$ A. Paczkowski, Prasa polonijna..., s. 41.
} 
246 czasopism, a każdego roku ukazywało się nie mniej niż 117. Zdaniem Roberta E. Parkera, autora słynnego opracowania pt. The Immigrant Press and Its Control, polonijna prasa osiągnęła apogeum swojego rozwoju podobnie zresztą jak prasa włoska - w połowie drugiej dekady XX w. ${ }^{32}$. To również okres znacznego rozproszenia polonijnego czasopiśmiennictwa co nie jest bez znaczenia w kontekście badania stopnia jego digitalizacji. Zdaniem Paczkowskiego, w sześciu największych ośrodkach skupisk polonijnych ukazywało się ogółem ok. 50 proc. wszystkich tytułów. Oznaczało to spadek o niemal 20 proc. w porównaniu z 1892 r. i 40 proc. w porównaniu z rokiem $1887^{33}$. Powołując się na dane z 1920 r. Parker wskazuje, że w Nowym Jorku ukazywały się 4 tytuły, w Chicago 11, Cleveland 6, Minneapolis 1, Filadelfii 5, Pittsburghu 3, St. Louis 1, zaś w Bostonie i Milwaukee po 2 tytuły. Łącznie, w dziesięciu największych miastach miało być wydawanych 35 pism, zaś w pozostałych ośrodkach $41^{34}$. Można mieć co prawda poważne wątpliwości, co do kompletności tych danych - zdaniem m.in. Paczkowskiego w 1920 r. ukazywało się co najmniej 155 tytułów polonijnych, w tym 20 dzienników - jednak bezsprzecznie wskazują one na tendencję decentralizacji tego segmentu prasy. Na początek lat 20. XX w. przypadł również najwyższy łączny nakład. Osiągnął on swoje apogeum w 1921 r., kiedy jednorazowo rozchodziło się 1,5 mln egzemplarzy prasy polonijnej.

Warto także zauważyć, że na początku trzeciej dekady XX w., a więc pod koniec badanego okresu, powstały pierwsze czasopisma polonijne wydawane wyłącznie w języku angielskim. Wiązało się to z faktem okrzepnięcia polskiej imigracji w Stanach Zjednoczonych oraz stopniowej asymilacji następnych pokoleń, urodzonych już w USA. W 1920 r. ukazywało się 5 takich tytułów, zaś siedem lat później było ich już 7, a w 1939 r. aż 30. Część polskojęzycznej prasy posiadała natomiast dodatki lub działy w języku angielskim. Tendencje te nasiliły się po 1924 r., a więc ostatecznym wprowadzeniu systemu kwotowego w polityce imigracyjnej USA i faktycznym zahamowaniu masowego napływu osób z Europy Południowej i Wschodniej.

${ }^{32}$ R. E. Park, The Immigrant Press..., s. 324.

33 A. Paczkowski, Prasa polonijna..., s. 50.

34 R. E. Park, The Immigrant Press..., s. 297. 


\section{Niekomercyine repozytoria cyfrowe}

Jak wynika z powyższej analizy, prasa polonijna w USA była rozproszona po całym kraju. Chociaż więc można wyróżnić główne ośrodki wydawnicze, jak Chicago, Nowy Jork czy Filadelfia, również w pozostałych miejscach osiedlenia polskich imigrantów funkcjonowały - z większym lub mniejszym powodzeniem - skierowane do nich czasopisma. Tym samym kwerenda zdigitalizowanych zasobów powinna objąć jeśli nie wszystkie stanowe biblioteki cyfrowe, to zapewne co najmniej te, w których zasięgu geograficznym ukazywało się najwięcej tytułów. Posługując się cytowanymi obliczeniami Parkera, a także dostępnymi danymi na temat wielkości skupisk polonijnych na przełomie XIX i XX w. w USA ${ }^{35}$, należałyby do nich repozytoria stanów Nowy Jork, Illinois, Ohio, Pensylwania, Massachusetts, Wisconsin, Michigan i Iowa. Biblioteki i repozytoria cyfrowe można podzielić na niekomercyjne oraz komercyjne, a także na te prowadzone przez osoby niezwiązane zawodowo z bibliotekoznawstwem czy archiwistyką. Wszystkie one funkcjonują równolegle w przestrzeni cyfrowej, co z jednej strony utrudnia poszukiwanie interesujących nas tytułów, z drugiej sprzyja szybkiemu powiększaniu zbiorów zdigitalizowanej prasy.

Jak do tej pory największym niekomercyjnym projektem związanym z digitalizacją prasy wydawanej w USA jest Chronicling America (www. chroniclingamerica.loc.gov). W 2003 r., we współpracy z National Endowment for the Humanities (NEH), Biblioteka Kongresu rozpoczęła realizację programu pn. „The National Digital Newspaper Program”, mającego za zadanie „stworzenie opartej na strukturze internetu oraz pozwalającej na swobodne przeszukiwanie bazy danych amerykańskich gazet i czasopism wraz z ich opisem i digitalizacją wybranych stron" ${ }^{36}$. Jest to zatem kontynuacja, a w zasadzie drugi etap, wcześniejszej inicjatywy pn. „The United States Newspaper Program". Prowadzony przez NEH w latach 1982-2011, miał on za zadanie opracowanie inwentarzy i katalogów oraz zachowania w formie mikrofilmów tytułów prasowych najbardziej

35 Por. Abstracts of Reports of the Immigration Commission, vol. 1, Washington 1911, s. 7.

${ }^{36}$ About Chronicling America [online] [dostęp 30 stycznia 2018]. Dostępny w World Wide Web: https://chroniclingamerica.loc.gov/about/. 
narażonych na zniszczenie ${ }^{37}$. Swoim zasięgiem program objął ogół prasy, ukazującej się w USA od 1690 r. do chwili obecnej. W efekcie powstał katalog liczący 154.792 tytuły czasopism. Uzyskane w ten sposób dane (140 tys. rekordów bibliograficznych oraz 600 tys. indywidualnych pozycji bibliotecznych) zostały następnie wykorzystane do sporządzenia listy tytułów prasowych przeznaczonych do digitalizacji. W 2004 r. NEH ogłosił regulamin naboru dla lokalnych instytucji, które chciały podjąć się digitalizacji, zaś rok później odbył się pierwszy konkurs i wybór kontrahentów. Lokalni grantobiorcy (biblioteki, stowarzyszenia historyczne itp.) otrzymali fundusze na wyselekcjonowanie i zdigitalizowanie ok. 100 tysięcy stron czasopism. Ze względu na założenia programu, a także niższe koszty, Biblioteka Kongresu nadała priorytet digitalizacji tych tytułów, które zostały już wcześniej utrwalone w formie mikrofilmów. Na chwilę obecną liczba zdigitalizowanych tytułów wyniosła 2493, co przełożyło się na ponad 12918917 pojedynczych stron ${ }^{38}$. W ramach Chronicling America dostępna jest prasa od 1690 r. do 1963 r., z zastrzeżeniem, że do domeny publicznej należą tytuły, które ukazywały się do roku 1923. Kwestię praw autorskich pozostałych wydawnictw, Biblioteka Kongresu pozostawia badaczom korzystającym z zasobów projektu.

Chronicling America oferuje podstawowe narzędzia do wyszukiwania. Można zatem ustawić wybrany przedział czasowy (roczny), zakres geograficzny (pojedynczy stan, grupa stanów lub cały kraj), numer strony, słowa kluczowe, frazę i język. Istnieje także możliwość wyboru konkretnego tytułu lub tytułów, spośród udostępnionych w bazie. Wyszukiwane słowa lub frazy wyróżnione są kolorem na tle całej strony czasopisma. Same zaś wyniki można segregować wg trafności, daty, miejsca wydania i tytułu pisma. W przeciwieństwie do bardziej zaawansowanych projektów, Chronicling America nie pozwala ograniczyć wyników jedynie do interesujących nas tekstów. Z jednej strony utrudnia to pracę, również pod względem technicznym, gdyż załadowanie całej strony wymaga czasu, nawet przy dobrym połączeniu internetowym. $Z$ drugiej, takie rozwiąza-

37 The National Digital Newspaper Program [online] [dostęp 30 stycznia 2018]. Dostępny w World Wide Web: https://www.neh.gov/divisions/preservation/national-digital-newspaper-program.

38 Stan na 15.03.2018 r. dane za: Chronicling America [online] [dostęp 15 marca 2018]. Dostępny w World Wide Web: https://chroniclingamerica.loc.gov/newspapers/. 
nie pozwala dostrzec otoczenie i kontekst, w których dana wypowiedź dziennikarska funkcjonuje ${ }^{39}$. Poważny mankament stanowi natomiast brak możliwości zapisywania wyników wyszukiwania oraz ustawień wyszukiwania, co oznacza, że każdorazowo badacz musi definiować wszystkie współrzędne od początku.

Wśród czasopism udostępnionych w ramach Chronicling America znajduje się 10 tytułów polonijnych ${ }^{40}$. Ich lista sporządzona w kolejności odpowiadającej liczbie zdigitalizowanych numerów wygląda następująco: „Dziennik Chicagoski” (3580 numerów), „Wiarus” (1375 i 381) ${ }^{41}$, „Ameryka” (465 i 121) ${ }^{42}$, „Jedność Polek” (397), „Telegraf” (371), „Dziennik Narodowy” (305), „Ameryka Echo” (170), „Katolik” (111), „Ameryka w Toledo i kuryer Clevelandski” (98), „Ameryka w Toledo” (14). Bliższa analiza dowodzi jednak, że faktyczna liczba zdigitalizowanych polonijnych tytułów jest mniejsza od deklarowanej. Wspomniane „Wiarus” i „Katolik” to w zasadzie jedno pismo, różniące się jedynie tytułem, co wynikało z przekształceń własnościowych wydawcy. W 1895 r. „Katolik”, po dwuletnim istnieniu, na powrót stał się „Wiarusem”. Podobnie rzecz się ma z „Ameryką”, „Ameryką w Toledo i kyryerem Clevelandskim” oraz „Ameryką w Toledo”, za którymi stały te same osoby. Wiele do życzenia pozostawia również kompletność zbiorów. Największa kolekcja w zbiorze prasy polonijnej, a więc kolekcja „Dziennika Chicagoskiego”, zawiera numery z lat 1890-1909, przy czym z 1890 r. dostępnych jest tylko 11 grudniowych numerów.

Mimo powyższych mankamentów, Chronicling America należy uznać za podstawowe cyfrowe repozytorium, udostępniające zbiory prasy polo-

39 Część badaczy zwraca uwagę, że ograniczenie wyników jedynie do wyszukiwanych tekstów nie pozwala na pełne zbadanie kontekstu, w którym one funkcjonują. Por. S. J. Potter, The Nineteenth-Century Press in the Digital Age (recenzja), "Victorian Studies" 2014, vol. 56, s. 554-555.

40 Strona internetowa Chronicling America podaję liczbę 13 czasopism w języku polskim, jednakże dwukrotnie wymienia „Ameryka Echo”. Również dwukrotnie są wymienione „Ameryka” oraz „Wiarus”, co wiąże się z podzieleniem ich zbiorów na dwie odrębne kolekcje.

41 Zbiory „Wiarusa” zostały podzielone na dwie kolekcje ze względu na przerwę w jego wydawaniu - w latach 1893-1894 ukazywał się jako „Katolik”. Do swojej starej nazwy „Wiarus” powrócił w $1895 \mathrm{r}$.

${ }^{42}$ Również zbiory „Ameryki” funkcjonują jako dwie odrębne kolekcje, co wiąże się z faktem, iż w latach 1891-1893 ukazywała się jako „Ameryka w Toledo i kuryer Clevelandski". 
nijnej wydawanej w USA w latach 1870-1924. Swoim zasięgiem obejmuje cały kraj, a otwarty charakter projektu i jego coroczna rozbudowa dają podstawy przypuszczać, że zbiór prasy polonijnej powiększy się o kolejne tytuły. Już obecnie pod względem liczby tytułów i zdigitalizowanych stron ustępuje on jedynie prasie niemieckojęzycznej, pozostawiając w tyle prasę włoskojęzyczną, irlandzką i żydowską. Warto także wspomnieć, iż mechanizm wyszukiwawczy dobrze sobie radzi z polskimi literami, choć zdarzają się także błędy w otrzymanych rezultatach. Chociaż Chronicling America, jako projekt federalny, uwzględnia lokalne zbiory prasy, warto przeanalizować poszczególne stanowe projekty digitalizacyjne, zwłaszcza dotyczące tych regionów, w których prasa polonijna wyraźnie zaznaczyła swoją obecność.

Digitalizacją dawnej prasy ukazującej się w Illinois zajmuje się the University of Illinois w Urbana-Champaign, której biblioteka posiada pokaźne zbiory stanowego czasopiśmiennictwa. Projekt pn. "Illinois Digital Newspaper Collections" (idnc.library.illinois.edu) nie dysponuje stałym finansowaniem, lecz opiera się na grantach oraz prywatnych dotacjach. W związku z tym do tej pory udało się zdigitalizować jedynie niewielką część posiadanych zbiorów. Na chwilę obecną w cyfrowej kolekcji znajduje się 116 tytułów prasowych (z lat 1831-2011), których łączna liczba dostępnych numerów wynosi $1470118^{43}$. System wyszukiwania i prezentowania wyników opiera się w znacznej mierze na rozwiązaniach stosowanych przez Chronicling America. Jedyna modyfikacja polega na możliwości wyszukiwania artykułu lub czasopisma po dacie dziennej. W zbiorach Illinois Digital Newspaper Collections znajdują się trzy polonijne tytuły - „Dziennik Chicagoski”, „Dziennik Narodowy” oraz „Telegraf". Są to jednakże te same kolekcje, które udostępnia także Chronicling America.

Dawne tytuły prasowe, ukazujące się w stanie Nowy Jork, są udostępniane poprzez stronę internetową pt. New York Historic Newspapers (nyhistoricnewspapers.org). Jest to wspólny projekt Northern New York Library Network i Empire State Library Network, w ramach którego pozyskiwane są już zdigitalizowane wersje czasopism od lokalnych instytucji, stowarzyszeń i osób prywatnych. Obecnie w ramach projektu udało się

${ }^{43}$ Stan na 01.02.2018 r. 
zgromadzić 618 tytułów prasowych z lat 1725-2016. Łączna liczba zdigitalizowanych i udostępnionych stron wynosi $7614840^{44}$. Nowojorskie zbiory należą zatem do jednych z największych tego typu w skali całego kraju. Strona oferuje podstawowe narzędzia do wyszukiwania, a więc wyszukiwanie po słowach kluczowych, dacie dziennej lub tytule. W stosunku do Chronicling America i Illinois Digital Newspaper Collection, prasę można przeglądać nie tylko posługując się kategorią miasta wydania, ale i hrabstwa. Niestety, mimo tak znacznej liczby tytułów, New York Historic Newspapers nie zawiera ani jednego tytułu polonijnego. Podobnie rzecz ma się z projektem pn. „Pennsylvania Historic Newspapers”, realizowanym przez tamtejszą bibliotekę stanową. Na stronie internetowej (digitalcollections.powerlibrary.org) jest udostępnionych 160 lokalnych tytułów prasowych, nie ma jednak wśród nich prasy polonijnej. Polonijne czasopiśmiennictwo jest również nieobecne w pozostałych stanowych bibliotekach cyfrowych, m.in. w Massachusetts i Michigan. W tym ostatnim projekt digitalizacji prowadzi biblioteka Central Michigan University, która na swojej stronie zamieściła listę lokalnych tytułów dostępnych w innych repozytoriach. Również w tym przypadku nie udało się odnaleźć polonijnej prasy z tego stanu. Z kolei Ohio nie posiada odrębnej biblioteki cyfrowej, lecz zbiory tamtejszej prasy dostępne są jedynie z poziomu Chronicling America i repozytoriów komercyjnych. Podobnie pozostałe zbadane stanowe biblioteki cyfrowe nie posiadają w swoich zbiorach tytułów polonijnych.

Do repozytoriów niekomercyjnych należy także zaliczyć, udostępniony przez niezależną bibliotekę naukową „Newberry” w Chicago, spis wycinków z prasy etnicznej z lat 1855-1938, tzw. „Foreign Language Press Survey"45. Sporządzony przez Chicago Public Library w 1942 r. liczy 120 tys. stron z fragmentami artykułów z prasy wydawanej przez 22 społeczności imigranckie w Chicago. Polskie zbiory należą do największych - zawierają bowiem 5490 wycinków, głównie z takich pism jak „Zgoda” i „Dziennik Chicagoski”. Mechanizm wyszukiwania interesujących nas fragmentów jest niezwykle uproszczony. Co więcej, fragmenty artykułów udostępnione są jedynie w języku angielskim. Z jednej strony

${ }^{44}$ Stan na 01.02.2018 r.

45 Foreign Language Press Survey [online] [dostęp 15 marca 2018]. Dostępny w World Wide Web: http://flps.newberry.org/. 
jest to mankament, gdyż badacz nie ma możliwości skonfrontowania ich z wersją oryginalną. Z drugiej jednakże, pozwala na porównanie prasy polonijnej z prasą wydawaną przez inne społeczności.

\section{Repozytoria amatorskie}

Do niekomercyjnych zbiorów cyfrowych należy zaliczyć także te prowadzone przez osoby prywatne, tworzone w ramach własnych zainteresowań lub też projektów naukowych. Przymiotnik „amatorskie” nie musi zatem odnosić się do wielkości oferowanych przez nie zbiorów czy też stopnia zaawansowania platformy udostępniania - prywatne repozytoria czasami posiadają bowiem możliwości dorównujące profesjonalnym bibliotekom cyfrowym - lecz określa ich tożsamość jako repozytoriów nie organizowanych przez przeznaczone do tego celu instytucje. Z tego względu, jak również ze względu na ich często efemeryczny i niekompletny charakter, należy opisać je w oddzielnej kategorii. Zaliczyć do niej można m.in. stronę internetową „IWW History Project”, prowadzoną przez naukowców z University of Washington, a dedykowaną dziejom radykalnego związku zawodowego „Robotnicy Przemysłowi Świata” (IWW) ${ }^{46}$. Wśród oferowanych przez nią materiałów, znajduje się (niekompletna) lista czasopism wydawanych przez IWW w USA, skonstruowana przez Kenyona Zimmera na potrzeby jego książki o żydowskim i włoskim anarchizmie w Stanach Zjednoczonych ${ }^{47}$. 0 niekompletności tej listy świadczy chociażby fakt, że zawiera ona tylko jeden tytuł wydawany w języku polskim, a mianowicie "Solidarność" drukowaną w Chicago w latach 1913-1917. Poszukiwania podobnych projektów wykazały, że prasa polonijna w USA cieszy się małym zainteresowaniem naukowców, chcących udostępnić w całości lub częściowo wykorzystane w swoich badaniach zbiory. Dotyczy to zarówno czasopism radykalnych, jak i religijnych czy związkowych.

${ }^{46}$ IWW Newspapers [online] [dostęp 15 marca 2018]. Dostępny w World Wide Web: http://depts.washington.edu/iww/newspapers.shtml.

${ }^{47}$ K. Zimmer, Immigrants Against the State. Yiddish and Italian Anarchism in America, Champaign 2015. 
Wiele z tytułów prasy polonijnej w USA było wydawanych przez organizacje kościelne lub stowarzyszenia religijne. W związku z tym warto zapoznać się z repozytorium prowadzonym przez Catholic Research Resources Alliance - „The Catholic News Archive”, które oferuje dostęp do czasopiśmiennictwa katolickiego w Stanach Zjednoczonych ${ }^{48}$. Na początku 2018 r. zbiory tego repozytorium liczyły 11 tytułów, spośród których najstarsze wydanie pochodziło z 1832 r., a najnowsze z 1978 r. Niestety, również w tym przypadku nie stwierdzono obecności polonijnej prasy religijnej.

\section{Repozytoria komercyjne}

Równolegle do powszechnie dostępnych bibliotek i repozytoriów cyfrowych, rozwija się rynek platform komercyjnych, z których można korzystać po wykupieniu prenumeraty. Jest ona najczęściej skierowana wyłącznie do instytucji naukowych, w tym przede wszystkim uniwersytetów i bibliotek różnego rodzaju. Rzadziej mogą z niej skorzystać osoby prywatne. Wysokie koszty prenumeraty, jak również ograniczenia instytucjonalne sprawiają, że dla polskiego badacza komercyjne repozytoria $\mathrm{z}$ archiwalnymi wydaniami prasy są trudno osiągalne. Warto jednak pamiętać, iż szeroką ofertę dostępu do bibliotek cyfrowych posiadają instytucje zagraniczne, oferujące stypendia naukowe. W przypadku badań związanych ze Stanami Zjednoczonymi, w tym także tamtejszą prasą polonijną, należy wspomnieć chociażby o holenderskim Roosevelt Institute for American Studies w Middelburgu i John F. Kennedy Institute for North American Studies w Berlinie, z których grantów badawczych skorzystało już pokaźne grono polskich badaczy ${ }^{49}$.

Największą z komercyjnych cyfrowych baz danych, oferujących dostęp do archiwalnych wydań prasy etnicznej w USA, jest „Ethnic American

48 The Catholic News Archive [online] [dostęp 18 marca 2018]. Dostępny w World Wide Web: https://thecatholicnewsarchive.org/.

${ }^{49}$ Informacje o oferowanych grantach dostępne są na stronach internetowych obu instytucji: Roosevelt Institute for American Studies [online] [dostęp 18 marca 2018]. Dostępny w World Wide Web: www.roosevelt.nl oraz John F. Kennedy Institut für Nordamerikastudien [online] [dostęp 18 marca 2018]. Dostępny w World Wide Web: www.jfki. fu-berlin.de. 
Newspapers from the Balch Collection, 1799-1971", zdigitalizowana nakładem Readex. Zawiera ona zbiory ponad 130 tytułów wydawanych przez różne grupy etniczne w 25 stanach, które wcześniej stanowiły podstawę Balch Institute of Ethnic Studies, połączonego w 2002 r. z Historical Society of Pennsylvania. Jak można przeczytać na stronie internetowej, znajdują się w niej m.in. czasopisma związane z imigrantami z Czech, Francji, Niemiec, Węgier, Irlandii, Włoch, Japonii, Litwy i Polski ${ }^{50}$. Przeprowadzona analiza tytułów wskazała jednak, że zawartość kolekcji nie odzwierciedla wielkości poszczególnych zbiorowości. Chociaż zatem najliczniej reprezentowana jest prasa niemieckojęzyczna (55 tytułów) co odpowiada liczebności imigrantów z tego obszaru językowego - to pozostałe mniejszości są bądź nadreprezentowane, bądź też niedoszacowane. Prasa polonijna należy do tej drugiej kategorii. Co prawda indeks zawiera cztery tytuły w języku polskim, lecz zaledwie jeden jest obecnie dostępny: „Ognisko” (lata 1887-1889, 46 numerów) ${ }^{51}$. Pozostałe, tj. „Ognisko Domowe” (lata 1929-1930), „Polonia w Ameryce” (1905) i „Wiadomości Codzienne” (lata 1916-1919) są oznaczone jako „forthcoming”, mają zatem zostać wprowadzone do bazy w najbliższej przyszłości ${ }^{52}$. Jak jednak widać, nawet zaktualizowane zbiory nie mogą być uznane za reprezentatywne dla polonijnego czasopiśmiennictwa w USA.

Readex jest również wydawcą „Early American Newspapers”53. Jest to największe komercyjne repozytorium, zawierające czasopisma wydawane w Stanach Zjednoczonych od końca XVII w. do połowy XX w. Obecnie liczy ono 12 serii, podzielonych chronologicznie, a w przypadku ostatniej serii, także tematycznie. Pomimo tak licznych i różnorodnych zbiorów, „Early American Newspapers" nie zawiera tytułów polonijnych. Czasopism polonijnych nie znaleziono również w innym komercyjnym repozytorium, tj. „Newspapers.com”. Brak tego segmentu prasy musi budzić zdziwienie,

${ }^{50}$ Ethnic American Newspapers from the Balch Collection, 1799-1971. New opportunities to explore the American immigrant experience [online] [dostęp 18 marca 2018]. Dostępny w World Wide Web: http://www.readex.com/content/ethnic-american-newspapers-balch-collection-1799-1971.

${ }^{51}$ Stan na 11.03.2018 $\mathrm{r}$.

52 Stan na 15.03.2018 r.

53 Early American Newspapers: By Series. An essential record of America across three centuries [online] [dostęp 15 marca 2018]. Dostępny w World Wide Web: http://www. readex.com/content/early-american-newspapers-series. 
zważywszy, że jego zbiory liczą ponad 7,1 tys. tytułów wydawanych w USA i nie tylko, co daję liczbę ponad $300 \mathrm{mln}$ zeskanowanych stron.

\section{Podsumowanie}

Analizując wszystkie typy repozytoriów cyfrowych, posiadających w swoich zbiorach prasę wydawaną w Stanach Zjednoczonych, należy podkreślić niewystarczającą obecność w nich tytułów polonijnych. Liczba, jak i zróżnicowanie czasopiśmiennictwa ukazującego się wysiłkiem polskich imigrantów w USA i ich potomków, nie znajdują swojego potwierdzenia w zbadanych repozytoriach. W konsekwencji, najważniejszym - i praktycznie jedynym - źródłem jest federalny projekt „Chronicling America”, który zawiera (niekompletne) zbiory takich tytułów, jak „Dziennik Chicagoski” i „Wiarus”. Szczególnie martwi nieobecność prasy polonijnej w stanowych bibliotekach cyfrowych, zważywszy na lokalny charakter większości wydawanych w USA na przełomie XIX i XX w. pism. Warto także zastanowić się nad brakiem interesujących nas tytułów w repozytoriach amatorskich, tworzonych przez osoby indywidualne lub stowarzyszenia. Dowodzi to nie tylko braku zainteresowania tego typu prasą, jako ważnym dziedzictwem lokalnej kultury, ale również sugeruje trudności z dotarciem do zbiorów wydawnictw polonijnych. Zapewne czynniki te zadecydowały o braku szerszej reprezentacji prasy polskojęzycznej również w repozytoriach komercyjnych.

Warto zauważyć, że prasa polonijna ukazująca się w USA nadal stanowi przedmiot zainteresowań wielu rodzimych badaczy. Mimo trudności z dotarciem do jej zbiorów, powstają ciekawe monografie i przyczynki. Niemniej, nie ulega wątpliwości, że większa obecność polonijnego czasopiśmiennictwa w zbiorach cyfrowych dałaby pozytywny impuls, dzięki któremu możliwe byłoby zbadanie także mniej znanych tytułów, jak również ułatwiłoby analizę na wielkich zbiorach danych, która w przypadku tradycyjnej formy mikrofilmów wymaga dużych nakładów osobowych i czasowych. Należy zatem wyrazić nadzieję, że polonijne czasopiśmiennictwo uzyska należne mu miejsce w cyfrowych zbiorach - zarówno amerykańskich, jak i polskich. 


\section{Bibliografia:}

Bingham Adrian, The Digitization of Newspaper Archives. Opportunities and challenges for historians, „Twentieth Century British History” 2010, vol. 21, s. 225-231.

Brożek Andrzej, Polonia amerykańska, Warszawa 1977.

Jaroszyńska-Kirchman Anna D., The Polish Hearst. Ameryka-Echo and the Public Role of the Immigrant Press, Chicago and Springfield 2015.

Kowalik Jan, Bibliografia czasopism polskich wydawanych poza granicami Kraju od września 1939 roku, t. 1-4, Lublin 1976.

Kruszka Wacław, Historya polska w Ameryce, t. V, Milwaukee 1905.

Kuzniewski Anthony J., The Polish-American Press, [w:] The Ethnic Press in the United States. Historical Analysis and Handbook, (red.) S. M. Miller, New York, Westport, London 1987, s. 275-290.

Nir Roman, Prasa polonijna w Ameryce, „Collectanea Theologica” 1982, nr 52, s. 197-206.

Paczkowski Andrzej, Prasa polonijna w latach 1870-1939. Zarys problematyki, Warszawa 1977.

Parker Robert E., The Immigrant Press and Its Control, New York and London 1922.

Radzik Tadeusz, Polonia amerykańska wobec Polski 1918-1939, Lublin 1990.

Skrzypek Józef, Początki czasopiśmiennictwa polskiego w Stanach Zjednoczonych $A P$, „Problemy Polonii Zagranicznej” 1960, nr 1, s. 155-186.

The Ethnic Press in the United States. Lists of Foreign Language, Nationality and Ethnic Newspapers and Periodicals in the U.S., New York 1974.

The Immigrant Labor Press in North America, 1840s-1970s. An Annotated Bibliography, vol. 2, pod red. Dirka Hoerdera, New York-Westport-London 1987.

Wasilewski Krzysztof, Bezdomnych gromady niemałe... Dyskurs imigracyjny na łamach prasy amerykańskiej (1875-1924), Poznań 2017.

Wasilewski Krzysztof, Co biblioteki cyfrowe mogq zaoferować prasoznawcom?, [w:] Książka, biblioteka, informacja. Między podziałami a wspólnota, t. V, (red.) J. Dzieniakowska, M. Olczak-Kardas, Kielce 2016, s. 649-664.

Wępsiec Jan, Polish American Serial Publications 1842-1966. An Annotated Bibliography, Chicago 1968. 


\section{Źródła elektroniczne:}

About Chronicling America [online] [dostęp 30 stycznia 2018]. Dostępny w World Wide Web: https://chroniclingamerica.loc.gov/about/.

Chronicling America [online] [dostęp 15 marca 2018]. Dostępny w World Wide Web: https://chroniclingamerica.loc.gov/newspapers/.

Early American Newspapers: By Series. An essential record of America across three centuries [online] [dostęp 15 marca 2018]. Dostępny w World Wide Web: http://www.readex.com/content/early-american-newspapers-series.

Ethnic American Newspapers from the Balch Collection, 1799-1971. New opportunities to explore the American immigrant experience [online] [dostęp 18 marca 2018]. Dostępny w World Wide Web: http://www.readex.com/ content/ethnic-american-newspapers-balch-collection-1799-1971.

[First World War] IWW Newspapers [online] [dostęp 15 marca 2018]. Dostępny w World Wide Web: http://depts.washington.edu/iww/newspapers.shtml. Foreign Language Press Survey [online] [dostęp 15 marca 2018]. Dostępny w World Wide Web: http://flps.newberry.org/.

John F. Kennedy Institut für Nordamerikastudien [online] [dostęp 18 marca 2018].

Dostępny w World Wide Web: www.jfki.fu-berlin.de.

Roosevelt Institute for American Studies [online] [dostęp 18 marca 2018]. Dostępny w World Wide Web: www.roosevelt.nl

The Catholic News Archive [online] [dostęp 18 marca 2018]. Dostępny w World Wide Web: https://thecatholicnewsarchive.org/.

The National Digital Newspaper Program [online] [dostęp 30 stycznia 2018]. Dostępny w World Wide Web: https://www.neh.gov/divisions/preservation/ national-digital-newspaper-program.

Wiffjes Huub, Digital Humanities and historical newspaper research [online] [dostęp 3 kwietnia 2016]. Dostępny w World Wide Web: https://www. kb.nl/sites/default/files/docs/huub-wijfjes-digital-humanities.pdf.

\section{The digitization of Polish-language press published in the United States in the years 1875-1924}

AвSTRACT: The article presents the quantity and the contemporary state of digitization of the Polish-language press published in the United States in the 
years 1875-1924, when the Polish immigration to the US reached its apex. The analysis has covered digital libraries and repositories of both: non-commercial and commercial usage.

KEYWORDS: polish-language press, digitization, digital libraries, immigration, USA, Chronicling America. 